Studia Anglica Posnaniensia 49/1, 2014

doi: 10.2478/stap-2014-0003

\title{
ANXIETY IN SPANISH EFL UNIVERSITY LESSONS: CAUSES, RESPONSIBILITY ATTRIBUTION AND COPING
}

\author{
PATRICIA ARNAIZ AND JESSICA PÉREZ-LUZARDO
}

Universidad de Las Palmas de Gran Canaria

\begin{abstract}
Few studies have focused on the anxiety experienced by learners of English as a foreign language in the context of Spanish universities. This study reports on the findings of an investigation into the sources of 216 Spanish university students' anxiety and incorporates two underexplored aspects in this area, namely, the responsibility students attribute to different agents and the perception students have of their own ability to cope during an anxiety episode. A qualitative/quantitative design was used. Results indicated that the primary source of anxiety related to the speaking skill. Quantitative analyses revealed that learners place the main responsibility for their anxiety on themselves and that women hold themselves responsible for their anxiety to a greater degree than men. The perceived coping ability of men and women was ranked below 'fair'. Theoretical and practical implications are discussed.
\end{abstract}

Keywords: anxiety, foreign language, self-perceived responsibility, self-perceived coping ability, university context

\section{Introduction}

Language learning is a cognitive activity that involves encoding, storing and retrieving information and anxiety can interfere with each of these processes. Students may find themselves in a divided attention scenario which requires them to centre on both the task and their reactions to it at the same time (MacIntyre 1995: 96). This, in turn, has proved to have negative effects for the language learning process, including lower course grades (Arnaiz \& Guillén 2012; Horwitz et al. 1986; Kondo \& Yang 2003; MacIntyre et al. 1997; Saito \& 
Samimy 1996), having difficulty in producing language (MacIntyre \& Gardner 1994), and communicating less with peers and teacher (Kondo \& Yang 2003; MacIntyre \& Gardner 1991).

Several attempts have been made to find a coherent way to explain, examine and present foreign language anxiety. Stroud and Wee (2006: 301) found two main types: Competence-based anxiety and identity-based anxiety. Learners are considered to experience competence-based anxiety when they do not feel confident of their command of the target language, and worry that their performance will be assessed by the teacher or by their peers (Kondo \& Yang 2003; Krashen 1981, 1982; Spolsky 1989). When learners cannot resort to their usual means of communication, they feel unable to express their true personality and cannot demonstrate their intelligence to the full (Burden 2004). As Horwitz et al. (1991) explain, language learners often have mature thoughts and ideas but an immature second (L2) vocabulary with which to transmit them. The inability to communicate language correctly and without obstacles causes disappointment and frustration. This can lead to unwillingness to communicate and may activate what Dayhoff (2000: 27) refers to as an "anxiety feedback loop", in which anxiety is prompted by the worry of being assessed by others in a performance situation. In these circumstances, learners may experience excessive fear of being humiliated or judged negatively in learning situations. Consequently, learners waste cognitive energy that could have been used for the task assigned, and have difficulty in concentrating and processing information; furthermore, the foreign language acquisition process slows down (Dewaele 2007).

Identity-based anxiety affects language learners when they are more worried about their relationship with other people than with their own language abilities. What makes these learners anxious is mainly their wish to be part of a particular group and to feel accepted and safe (Norton 2000).

Other authors have focused on different factors to explain student anxiety. Samimy (1994) and Aida (1994), for instance, studied factors related to the instructor, such as a judgmental attitude or a rigid style of managing the class group. Young (1990) presented a list of the activities that students find anxietyinducing: spontaneous role play, speaking and presenting a prepared dialogue in front of the class; being corrected in front of the class and being evaluated negatively by either the instructor or peers. To these anxiety-generating situations/activities, Williams and Andrade (2008: 186) added three: long silences that occurred when they were trying to find the right word to express themselves in front of the whole class; having to employ simple or broken language; and delivering a prepared speech by reading aloud.

But apart from students' language competence, their worry about losing face in front of peers and certain teachers' classroom management techniques, aspects of self-perception and self-esteem have been identified as key factors in 
the development of foreign language anxiety (FLA) (Cheng 2002; Horwitz et al. 1986; Price 1991; Onwuegbuzie et al. 1999). Correlational studies have shown a strong relationship between learners' self-perceptions of L2 command and anxiety. In fact, it has been demonstrated that learners' self-evaluated competence is a better predictor of anxiety level than actual L2 performance in language tests (Cheng 2002; Clément et al. 1994; Gardner \& MacIntyre 1993). This is consistent with the cognitive self-evaluation theory of the causes of social anxieties, which states that the main reason why people become anxious in social contexts is not that they lack the necessary skills, but rather that they believe they lack them and consider themselves unsuitable (Atkinson et al. 1994; Schlenker \& Leary 1985). If this theory is applied to language learning, a student may experience anxiety when using the target language because s/he thinks her/his L2 ability or competence is weak, thus expects to perform poorly and anticipates negative results. Several empirical studies support this hypothesis: negative correlations between self-perceived competence in the L2 and anxiety level have been found; learners who see themselves as less competent tend to suffer higher anxiety levels, while those with a more positive perception of their own performance tend to score low (Clément et al. 1994; Kitano 2001).

Two other relevant aspects of self-perception come into play when addressing the study of anxiety episodes: the attribution of responsibility students make regarding the anxiety experienced and the perceptions students have of their coping abilities to act in such situations. None of these issues, however, has been explored to any great extent in the English as a foreign language (EFL) literature. Only the study conducted by Williams and Andrade (2008) with Japanese university learners of English has directed its attention to both aspects. The results revealed, on the one hand, that most students attributed the cause of anxiety to the teacher or other people and that most of them felt frustrated and helpless in such situations and, on the other hand, that more men than women felt they could have a positive influence on the particular situation described. Another study of interest in this regard was carried out by Matsumoto et al. (1988: 279). The authors analyzed the responses of Japanese and American university learners to a series of experiences concerning anger, disgust, fear, guilt, joy, sadness, and shame. The aim of their research, which belongs to a different field of study but the results of which are pertinent here, was to examine the ecology of emotional experience, the regulation and control of emotion, the subjective evaluation of emotion-eliciting events, and the verbal, nonverbal, and physiological reactions. Their results indicated that American participants tended to assign the cause of the event to other people, and Japanese students tended to put it down to chance or fate. The two groups also differed in their view as to the need to act in emotion-eliciting actions: the number of students who believed action could be taken was higher in the American group. There- 
fore, as the authors explain, responsibility attribution and coping ability are interconnected: if a person does not assume her/his responsibility for an event or holds other agents responsible, the ability to cope may be limited.

Finally, it is important to bear in mind that in spite of the effort made by researchers and educators to help learners tackle anxiety, a certain level of anxiety is positive for the EFL class. In fact, it has been postulated that the function of anxiety is bidirectional, that is, the concept can be split into facilitating and debilitating anxiety (Chastain 1975; Scovel 1978). The former motivates learners to face the new learning task and stimulates them emotionally to take the most appropriate decisions; the latter, by contrast, may motivate the learner to avoid a particular learning task. This implies that a moderate level of anxiety can be a motivating factor for students (Ewald 2007; Zhang 2001) and even enhance their learning (Spielmann \& Radnofsky 2001). However, when learners feel little or no anxiety, they may not consider the tasks demanding enough, they may find them boring or evade their responsibilities as language learners.

\section{Present study}

This research responds to Hewitt and Stephenson's (2012: 170) suggestion that "continued research into language anxiety matters" not only because it has been proved to be a relevant variable in the foreign language learning process but also because it is a variable that may allow for action on the part of the teachers. To this end, this study investigates students' perceptions of selected anxiety-related aspects in the context of University English classes in Spain, thereby offering a new perspective on a long-recognized problem. An open-ended question about past anxiety episodes and two closed questions about attribution of responsibility for their anxiety and coping abilities were answered by the group of students participating in the study.

No research has been found in the literature recording the different situations that cause anxiety to Spanish university learners of English from a qualitative perspective while also complementing such data with a quantitative analysis of student attribution of responsibility for their anxiety to different agents together with students' self-perceived coping ability. A review of the literature reveals that only the study by Williams and Andrade (2008), carried out with Japanese university students of English, has directed its attention to similar aspects and has employed similar analyses. Other studies have focused on learners' own experience with anxiety but have addressed it from different perspectives and with varied student profiles. For example, in Ewald's research (2007), participants were university students of Spanish; Fukai (2000) conducted his research with USA university students of Japanese; Liu (2006) with Chinese university learners of English; and Zhang's (2001) research was carried out with Singaporean university learners of English. 
Although crucial for an understanding of anxiety and its role in foreign language learning, the findings of these previous studies are not applicable to the context of our investigation; it is therefore of the utmost importance to carry out this type of research in the setting we describe in this paper. As Wesely (2012: 105) recommends, we need to be able to draw on different types of evidence if our aim is to further knowledge about language learners and the language learning process. Since the diversity of learner characteristics, beliefs and perceptions is as broad as the contexts they belong to, it cannot be considered that the situations of anxiety and perceptions detected in a certain group of students are illustrative of students with other profiles (Liu 2006; Rifkin 2000).

The research revolved around the following research questions:

1. Which class situations provoke anxiety in Spanish university students of English? (Excluding exam situations)

2. Who do students hold responsible for the anxiety episode they chose to describe? Is there any difference between women's and men's perceptions of responsibility for anxiety?

3. How do students evaluate their ability to act in the particular anxiety situation described? Is there any difference between women's and men's perceptions of their coping abilities?

3. Method

\subsection{Participants}

The sample consisted of 216 Spanish university students, 120 females $(55.5 \%)$ and 96 males $(44.5 \%)$. Their ages ranged from 18 to $39(M=20.39 ; S D=3.69)$. 156 of the students were studying Teacher Training, while the other two groups of students came from the Translation and Interpreting Faculty (30) and the Computer Science Faculty (30).

Their language levels in English ranged from B1 to C1: 117 were B1-level students, 87, B2-level and the remainder, 12, C1-level. English class groups at university are organized according to these levels, established following The Common European Framework of Reference for Languages: Learning, Teaching, Assessment (CEFR) (2001), a guideline used to describe foreign language learners' achievements across Europe ${ }^{1}$.

The participation of these individuals was voluntary and their written approval obtained.

1 The 2008 study by Martínez Baztán has addressed correspondence with the The American Council on the Teaching of Foreign Languages (ACTFL) Guidelines. Thus, B1 would correspond to Intermediate Mid and Intermediate High, B2 would correspond to Intermediate High and Advanced Low, and C1, to Advanced Mid, Advanced High. 


\subsection{Data elicitation tools}

The data elicitation tools used included an adapted version of the questionnaire employed by Williams and Andrade (2008) in their study with Japanese university EFL learners. The questionnaire included four questions which required either free or structured responses. For the purposes of the research presented here, the responses to three of the questions were analyzed. The first was an openended question about a specific situation that had provoked anxiety in students this question was taken directly from Williams and Andrade's paper. In the second question, students had to indicate on a four-point Likert scale, ranging from 1 (not at all) to 4 (a lot), the extent to which they perceived four agents to be responsible for the particular anxiety situation described - in Williams and Andrade's paper subjects were given nine options, but could not rank their perceived responsibility. In the third question, participants were asked to rate their ability to cope in that particular anxiety situation. A five-point Likert scale was used on this occasion, ranging from 1 (very poor) to 5 (very good), while in Williams and Andrade's students were given five statements regarding their ability to cope on which they had to show their agreement or disagreement.

Furthermore, a background questionnaire, including some demographic information such as language level, gender and age was also included.

\subsection{Procedure}

Permission was requested from the deans of the three Faculties involved to conduct the survey.

Once the researchers had explained the purpose of the study, the participants were asked to complete the background questionnaire. Subsequently, the students were given the questionnaire and the researchers read the written instructions aloud, encouraging the participants to ask questions if they did not understand the directions.

Subjects completed the questionnaire in the second semester of the academic year during class time. Learners were assured that the results would not have any effect whatsoever on their final mark or on their academic record. The researchers also confirmed that the data gathered would be treated with complete confidentiality.

\subsection{Data analysis}

Different analyses were conducted to analyze the three research questions selected.

A qualitative analysis was performed to assess the sources of anxiety for university students during class time. This qualitative analysis was done in five 
steps. Firstly, the descriptions given by students were read by the two authors of this paper and organized into small units of basic ideas. Each basic idea unit, together with participants' original comments, was transferred to a table and preliminary codes were allocated. A subsequent rereading of the original data allowed patterns to be more rigorously identified, and answers in which similar aspects were mentioned were grouped together. Thirdly, the themes previously generated were converted to more abstract theoretical constructs, each of which was then broken down into subcategories in order to examine students' sources of anxiety in a more detailed manner. Finally, a definitive coding scheme was designed (Brown 2001). As two codes had to be assigned in some cases, contingency analyses were performed.

As for the items relating to responsibility for anxiety feelings and selfperceived ability to cope in the previously described anxiety situations, descriptive statistics were calculated. Subsequently, the non-parametric Mann-Whitney $\mathrm{U}$ test was performed to determine if there were any significant differences in the distribution of responsibility attributions and self-perceived coping abilities caused by gender. The variable level, taken into consideration for data collection, was not used in the statistical analysis. Although level has proved to be a determining factor in learner's anxiety levels (Arnaiz \& Guillén 2012; Liu 2006), it was not within the scope of this research to correlate level and sources of anxiety.

\section{Results}

\subsection{Class situations that provoke anxiety}

The qualitative analysis corresponding to the open-ended responses in which students described situations that provoked anxiety revealed seven main thematic affinities related to anxiety. Three of them were related to three language skills, speaking, listening and reading. In these cases anxiety was generated in situations that required having to produce oral language, having to listen to language, and having to read. The fourth one was related to feelings; it was the fear of experiencing certain feelings rather than actually experiencing them that made students feel anxious. The fifth thematic affinity concerned the teacher; these comments referred to the classroom management techniques teachers used in class, their philosophy and how they behaved and addressed the group. The sixth source of anxiety reported by students was related to aspects of the language learning process itself. Finally, peers constituted a further thematic affinity identified: these comments referred to peers' behavior and peer relationships.

The anxiety-triggering situations identified are summarized in Tables 1 and 2. Table 1 includes those sources of anxiety related to language skills and Table 
2 contains the sources of anxiety related to agents. It can be seen from the data in Table 1 that speaking was responsible for most of the anxiety suffered by learners. In particular, oral presentations provoked the most anxiety, as shown in the following quotation:

[307] Hablar en frente de la clase durante una presentación en inglés. [Giving an oral presentation in front of the class.]

Just having to express themselves in the foreign language was also often considered a source of anxiety. The specific reason reported in six cases by students was the lack of preparation time:

[273] En clase de inglés he llegado a sentir ansiedad cuando sé que tengo que contestar a algo sobre la marcha, porque necesito pensar lo que quiero decir. [I have experienced anxiety in the language class when I have had to give an answer straight away, because I need to think about what I want to say]

A second important source of anxiety for these students involved the teacher (as shown in Table 2). This category comprised $23.1 \%$ of all the anxiety sources identified and included all the decisions taken by teachers and their applications in the classroom context. One student addressed the anxiety caused by the teacher asking her/him to speak commenting:

[184] Cuando el profesor me pide que hable en inglés en público o que explique un ejercicio, porque me pongo muy nerviosa. [When the teacher asks me to speak in English in class or to explain an exercise, because I get very nervous]

[121] Cuando el profesor escoge al azar al alumno para que salga a la pizarra o explique algo delante de la clase. [When the teacher chooses somebody at random to go to the blackboard or explain something to the whole group]

[122] Cuando me han hecho una pregunta en alto. [When I have been asked a question out loud (in the big group)]

Issues related to listening (20.8\%) and feelings (14.4\%) were the next most frequently cited. With regard to listening (see Table 1), many students claimed to feel anxious when they were not able to understand either the teacher or their peers. One student pointed out: 
[252] Cuando me preguntan y no entiendo la pregunta, aunque me la repitan, y todo el mundo es capaz de entenderla menos yo. [When I'm asked a question and I don't understand the question, even if it is repeated, and everybody but me can understand it]

In the feelings category (see Table 2), the comments made by the learners were varied. The majority were related to their fear of falling behind, their high expectations regarding their performance and their reluctance to being observed, as shown in the following examples:

[141] Cuando veo que mis compañeros se defienden mejor que yo en la materia. [When I see that my peers do better than me in the subject] [172] Varias veces que creo que podría hacer mucho más o dar mucho más de mí misma y no lo hago. [Very often I think that I could do much more or make a greater effort and I don't]

[262] Sentirme observada en una exposición oral, no tener claro el guión que debo exponer. [Feeling observed in an oral presentation, not being clear about what I'm going to present]

In their responses, some students mentioned more than one source of anxiety. Contingency analyses enabled us to observe that of 118 students who mentioned speaking as a source of anxiety, 27 incorporated the teacher in the description of the situation and 13 added some type of feeling. In the example below we can see a student describing a situation in which s/he has to perform an oral presentation (speaking category) and makes explicit reference to the teacher (teacher category):

[231] Durante la exposición del libro en tercer curso, ya que al no conocer demasiado al profesor, no me inspiraba confianza y sabía que no lo estaba haciendo todo lo bien que podía. [In the oral presentation on the book, in the third year, as I did not know my teacher very well, I didn't feel very confident and I knew I was not doing my best]

One student addressed the anxiety involved in producing language (speaking category) and the fear of making mistakes in the English class (feelings category), commenting:

[284] Cuando he tenido que hablar en inglés y por miedo a equivocarme he sentido ansiedad. [When I have had to speak in English in class, and for fear of getting it wrong, I have felt anxious] 
In other cases (10), students identified a situation in which both their inability to understand what the teacher says (listening) and their fear of falling behind (feelings) are present as anxiety-generating. One student explained:

[112] Cuando la profesora da una explicación en inglés y no me he enterado de nada, ves que todo el mundo entiende, menos yo, y sólo puedo esperar a que alguien me lo explique [When the teacher explains something in English and I can't understand a word, I see everybody but me understands, I have no choice but to wait till somebody explains it to me]

The last three situations considered by students to provoke anxiety were related with reading aloud, with the language learning process itself and with peers.

Due to the appearance in some cases of more than one source of anxiety per student, as explained earlier, the numbers in Tables 1 and 2 do not coincide with the total number of students.

Table 1. Sources of anxiety: language skills

\begin{tabular}{|c|c|c|c|c|c|}
\hline$(N=216)$ & $n$ & $\%$ & $(N=216)$ & $n$ & $\%$ \\
\hline SPEAKING in L2 & 118 & 54.6 & LISTENING & 45 & 20.8 \\
\hline Oral presentation & 26 & 12.1 & $\begin{array}{l}\text { Not being able to } \\
\text { understand what the teacher } \\
\text { says }\end{array}$ & 27 & 12.5 \\
\hline $\begin{array}{l}\text { Oral presentation } \\
\text { without time for } \\
\text { planning }\end{array}$ & 3 & 1.4 & $\begin{array}{l}\text { Not being able to } \\
\text { understand }\end{array}$ & 11 & 5.1 \\
\hline Speaking in L2 & 24 & 11.1 & $\begin{array}{l}\text { Not being able to } \\
\text { understand because of the } \\
\text { speaker's speed }\end{array}$ & 3 & 1.4 \\
\hline $\begin{array}{l}\text { About a topic I'm not } \\
\text { sure about }\end{array}$ & 3 & 1.4 & OTHERS & 4 & 1.9 \\
\hline $\begin{array}{l}\text { Without time for } \\
\text { planning }\end{array}$ & 6 & 2.8 & & & \\
\hline $\begin{array}{l}\text { Not being able to } \\
\text { express myself }\end{array}$ & 16 & 7.4 & READING & 16 & 7.4 \\
\hline Big group & 11 & 5.1 & Reading aloud in L2 & 8 & 3.7 \\
\hline
\end{tabular}




\begin{tabular}{lcc|lcc}
$\begin{array}{l}\text { Not being able to give } \\
\text { an answer }\end{array}$ & 12 & 5.5 & $\begin{array}{l}\text { Reading aloud because of } \\
\text { my bad } \\
\text { pronunciation } \\
\text { Not being able to } \\
\text { understand what I read. }\end{array}$ & 2 & 0.9 \\
$\begin{array}{l}\text { Lack of } \\
\text { communicative }\end{array}$ & 10 & 4.6 & 1.4 \\
$\begin{array}{l}\text { competence } \\
\text { OTHERS }\end{array}$ & 7 & 3.3 & Own work & 3 & 1.4 \\
\hline
\end{tabular}

Table 2. Sources of anxiety: agents

\begin{tabular}{|c|c|c|c|c|c|}
\hline$(N=216)$ & $n$ & $\%$ & $(N=216)$ & $n$ & $\%$ \\
\hline FEELINGS & 31 & 14.4 & TEACHER & 50 & 23.1 \\
\hline $\begin{array}{l}\text { Fear of falling behind } \\
\text { and high expectations }\end{array}$ & 18 & 8.3 & $\begin{array}{l}\text { Classroom } \\
\text { management }\end{array}$ & 29 & 13.5 \\
\hline $\begin{array}{l}\text { Feeling observed }+ \\
\text { being afraid of being } \\
\text { laughed at }\end{array}$ & 9 & 4.1 & Teacher's presence & 5 & 2.3 \\
\hline I feel offended & 1 & 0.5 & Unfair treatment & 4 & 1.9 \\
\hline $\begin{array}{l}\text { Fear of making } \\
\text { mistakes }\end{array}$ & 2 & 0.9 & Using new language & 3 & 1.4 \\
\hline $\begin{array}{l}\text { Fear of lack of } \\
\text { knowledge }\end{array}$ & 1 & 0.5 & Evaluation & 3 & 1.4 \\
\hline PEERS & 6 & 2.8 & Bad teachers & 3 & 1.4 \\
\hline Noisy classmates & 4 & 1.9 & $\begin{array}{l}\text { Teacher upset because of } \\
\text { student's lack of competence }\end{array}$ & 2 & 0.9 \\
\hline $\begin{array}{l}\text { Poor relationship with } \\
\text { peers }\end{array}$ & 2 & 0.9 & $\begin{array}{l}\text { No support or } \\
\text { encouragement }\end{array}$ & 1 & 0.5 \\
\hline $\begin{array}{l}\text { LANGUAGE } \\
\text { LEARNING } \\
\text { PROCESS } \\
\end{array}$ & 9 & 4.2 & & & \\
\hline
\end{tabular}

Table 3 provides information on students' perception as to who they consider responsible for their anxiety. Some interesting outcomes appeared in relation to this question. Participants give themselves the highest score, followed by the teacher. The non-parametric Mann-Whitney $U$ test found significant malefemale differences on responsibility attribution: women consider themselves 
responsible for the anxiety situation described to a greater extent than men. Table 3 also gives information concerning the participants' perceived ability to cope. The mean rate participants attributed to themselves is 2.76 . No significant gender differences were detected.

Table 3. Means and standard deviations of responsibility attribution and coping perception and results of Mann-Whitney U Test according to gender.

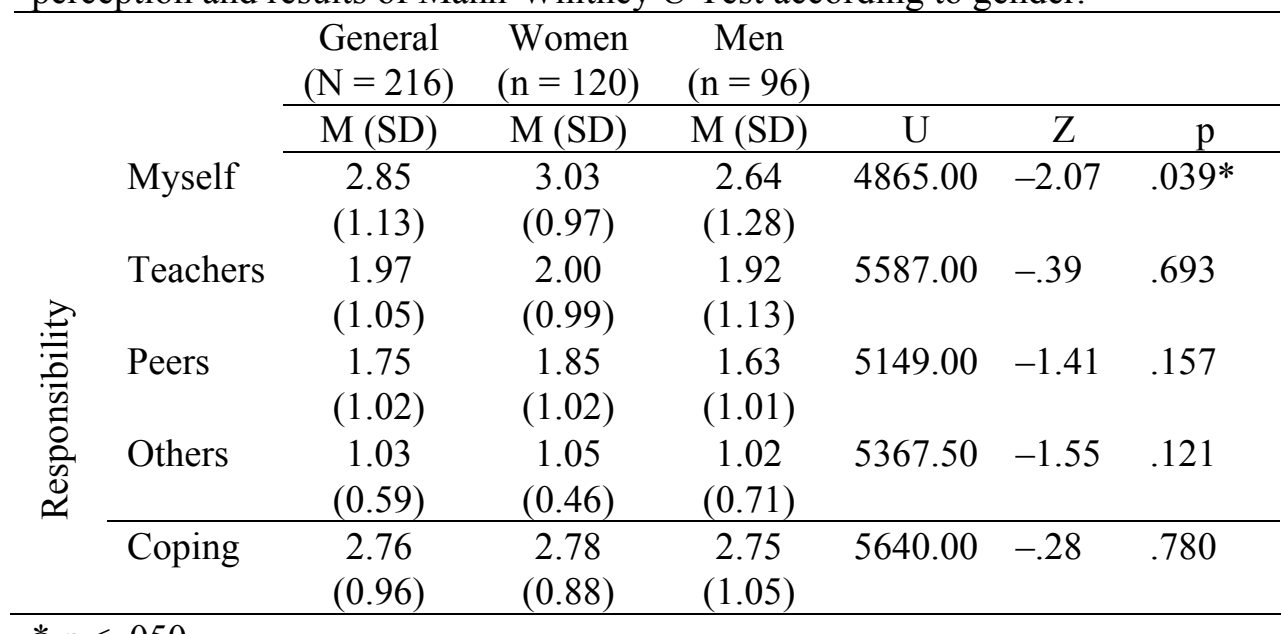

$* p<.050$

\section{Discussion}

The purpose of this study was to explore, in the first place, the types of situation that make students feel more anxious; secondly, to find out who the students considered to be responsible for the anxiety they felt; thirdly, to examine how respondents evaluated their ability to cope in those situations; and finally, the researchers analyzed whether gender determined how students attributed the responsibility for their anxiety and also the degree of self-perceived ability to copA number of important findings resulted from this study. Anxiety was most often associated with speaking, also called output. This anxiety refers to the apprehension students feel when they have to produce language. High anxiety at this stage may interfere with students' ability to speak the foreign language. Anxiety related to speaking was mainly associated in this research with oral presentations and speaking in L2 in class. These findings are consistent with those reported by Frantzen and Magnan (2005) in their qualitative analysis of the descriptions of the factors that increase anxiety written by 35 USA learners of French and Spanish.

Furthermore, and also related to the speaking skill category, anxiety was associated by the students in this study with processing (mental planning), al- 
though to a lesser degree. At the processing stage, students experience feelings of apprehension when they carry out cognitive tasks as a reaction to external stimuli. The degree of anxiety experienced in this phase seems to be determined by the difficulty of the stimuli, the extent to which memory is required and the way the material is presented (Tobias 1986). This evidence confirms what other studies have already described about the relevance of providing students with time to gather their thoughts and prepare their discourse before they speak (Arnaiz Castro et al. 2010; Burden 2004; Williams \& Andrade 2008).

It is worth noting that only 2 students considered pronunciation to be a reason for feeling anxious. This result differs from those of Williams and Andrade's study (2008), which found that poor pronunciation was a common source of discomfort. Taking into account that students' anxiety in language learning is generally linked to their weaknesses and failures, this result requires careful examination. The absence of pronunciation as an anxiety-generating factor in our study can be interpreted in two different ways: it can either be assumed that students believe their pronunciation to be acceptable or it can be understood that students, although aware of this limitation in the target language, do not consider it important. Whichever interpretation we choose, what is clear is that measures should be taken in this respect. On the one hand, and as has been demonstrated, Spanish people do not have a very good command of the English language nor very good pronunciation or intonation (see EF, English Proficiency Index 2012), therefore not being conscious of their weakness in this facet of the language is a problem. As stated by some authors (de Bot 1996; Swain 1995), becoming aware of one's weaknesses is not the same as solving them, but is surely a starting point from which to take measures and pave the way to improvement. On the other hand, consciously ignoring the importance of pronunciation and intonation when communicating reflects total ignorance of what being competent in a foreign language involves.

After the speaking skill, the aspects that generated the two other most common sources of discomfort were the teacher and the listening skill. In many cases it was being forced to speak that students considered most anxietygenerating. These results corroborate those obtained by Burden (2004) in his analysis of 289 questionnaires corresponding to first-year students during English conversation classes at a university in Western Japan and by Ewald (2007) in his research with 21 advanced students of Spanish. Williams and Andrade (2008) have suggested two possible solutions to this problem. One would be to provide prompts to produce a successful response; another technique would be to teach learners a variety of utterances such as "I don't know the answer to your question, maybe one of my classmates can help me' or 'could you help me?" These conversational strategies would perhaps help students feel a bit more in control of the conversation and would reduce their anxiety levels. 
As regards the anxiety caused by the inability to understand a new word or phrase, the results obtained are in line with those in Burden's study (2004). Students' ability to pay attention to, to focus on and to encode external stimuli is decisive; a high level of anxiety may reduce the amount of stimuli processed by the memory or subsequently retrieved and this, consequently, hinders learning.

Another common source of anxiety revolved around students' own feelings. Some students found it hard to accept that they would make mistakes when they spoke and they constantly felt that they were falling behind. Learners used peers as a benchmark and part of their perceived failure was attributed to the belief that their classmates' knowledge of English and ability exceeded their own. These findings are consistent with the results obtained in other studies. In the research carried out by Burden (2004), forty six percent of students believed that their classmates did better in English than them. Likewise, in the study by Yan and Horwitz (2008), some students referred to the difference in language abilities between themselves and their peers as a source of anxiety. As indicated by Yan and Horwitz (2008), this comparison with peers can be beneficial for the language learning process, provided it encourages learners to work harder.

This fear of making mistakes, together with maintaining high expectations regarding their class performance and the fear of being laughed at can all be said to be a result of a desire for perfectionism when producing language. This connection between perfectionism and anxiety was highlighted by Gregersen and Horwitz (2002) in their research. Perfectionist students set themselves unreasonably high performance standards and the impression they make on others, both academically and personally, is one of their main concerns. One possible approach to help learners solve this problem would be to introduce whole-group discussions about their feelings and their expectations. It is the teachers' task to help students understand that the class is not only a place for "demonstrating knowledge and skill, but also for gaining it" (Gregersen \& Horwitz 2002: 570). The acceptance of mistakes by both the teacher and learners should be a key principle in the foreign language learning process. Learners should be continuously reassured that although they may be nervous, these feelings should not make them feel unhappy about their learning. As Oxford indicated (1999), students would benefit from verbalizing and reflecting on what they feel to be anxiety-generating situations and observing that their peers often experience the same feelings. Encouraging students to identify their fears and assimilate that anxiety situations are transitory may help them to face those situations more realistically.

Furthermore, as Stroud and Wee (2006: 301) point out, much of the frustration students feel when they speak could perhaps be alleviated with more time for rehearsal. Language teachers must effectively communicate to students that learning a foreign language implies constant repetition and plenty of prepara- 
tion. For example, teachers could place special emphasis on guiding learners in the use of appropriate material that helps students prepare at home so that they can come to class feeling confident.

Another element of interest in the present study is the fact that it was the big group context that provoked student anxiety. The small-group context was mentioned only once. Although students did not make explicit reference to class arrangements, it can be assumed that the whole group was always present in students' minds when they described anxiety-generating situations. In this regard, it is important to mention the results of Frantzen and Magnan's (2005) qualitative analysis with 35 USA learners of French and Spanish that highlight the particular value of small group work or pair work to create a higher comfort level in class and a sense of classroom community. The results obtained by Suwantarathip and Wichadee (2010) in their study on the impact of cooperative learning on anxiety and proficiency in an EFL class point in the same direction. These authors interviewed six learners about their feelings when working with peers and all of them found the small-group work context to be a supportive environment where they did not feel anxious at all and did not worry about making mistakes

As for responsibility issues, a relevant finding for the language learning process and for the language learning sessions was that participants gave the highest score to themselves, and that in this particular case women considered themselves significantly more responsible than men. The teacher ranked second. These results point to a notable difference between our study and the study carried out by Williams and Andrade (2008). In their case, the highest score was given to the teacher while the students ranked second.

Peers appeared in third place. In line with the findings of Ewald (2007: 130), the learners in this study did not consider each other to be a serious cause of anxiety, since they are all 'in the same proverbial boat'.

The fact that these students did not attribute all the responsibility for their anxiety to their teachers but admitted their own role makes teachers' and researchers' tasks easier. It is definitely easier to help a learner who admits his failings than to help a learner who does not.

In response to the question about their perceived ability to cope with the anxiety-inducing situation, students indicated that their ability was slightly below "fair". No gender differences were detected on this occasion. In the study by Williams and Andrade, results can be said to point in the same direction, although to a greater extent: most students felt frustrated and bereft of resources.

Apart from Williams and Andrade's work (2008), no other study that includes foreign language learners' self-evaluations of coping strategies has been found, but the relevance of L2-related beliefs has been emphasized by several authors as potential contributors to FLA (Ganschow et al. 1994; Horwitz 1990, 1995; Young 1991). For example, in the study by Tóth (2007), results show that 
underestimated proficiency may have contributed to a lower L2 self-image and higher anxiety whereas overestimated proficiency may have led to an increase in students' L2 self-image and a decrease in their anxiety levels. This is consistent with the cognitive self-evaluation theory of the reasons for social anxiety described at the beginning of this paper, which explains that the main reason why people become anxious in social meetings is not that they lack the necessary strategies, but rather that they believe they lack them and consider themselves inadequate (Schlenker \& Leary 1985).

\section{Conclusion}

This study sheds light on the complex issue of anxiety among university Spanish learners of English. On the one hand, it provides teachers and researchers with evidence of a wider and very detailed variety of anxiety situations in the classroom. Although it is true that many of the responses were consistent with the foreign language anxiety construct designed by Horwitz et al. (1986), it is also true that the qualitative research presented in this paper permits a thorough analysis of the situations that may make learners feel anxious and can provide important insights into identifying other sources of anxiety. Certain issues regarding the teacher and the reading skill, for instance, are not included in Horwitz et al.'s Foreign Language Classroom Anxiety Scale (FLCAS). Furthermore, this type of research encourages reflection to a greater extent than closed questions and allows students the possibility of establishing connections between different sources of anxiety. This is in line with Spielmann and Radnofsky (2001), who argue that qualitative research strengthens statistical findings and makes the peculiarities of the language learning experience easier to understand.

On the other hand, inviting learners to describe certain anxiety episodes gives researchers and teachers access to their 'no-concerns'. The scant number of references to pronunciation is a valuable piece of information for teachers and researchers. Similarly, it could be assumed that those classroom contexts not mentioned are considered by students as 'favorable experiences', but this cannot be asserted without further research data. Future investigation could therefore focus on favorable or anxiety-free classroom situations in the context of Spanish universities. This type of information would enable teachers to design more realistic lesson plans for their sessions and adapt their classroom management with the aim of facilitating oral performance and trying to eliminate classroom practices that hinder success in the speaking of foreign languages. Understanding university students' sources of anxiety is an essential part of understanding how to intervene.

In addition, this paper opens up a line of research in the context of Spanish universities that could optimize outcomes for foreign language learners. Evalua- 
tion on the part of the learners of self-perceived responsibility and selfperceived coping abilities should be incorporated in future studies so as to further explore the link between these aspects and anxiety levels.

Finally, one main limitation must be acknowledged in this paper. Although strictly systematic procedures for collecting and examining data were followed in this research, any interpretation of verbal data is susceptible to subjectivity and bias. Incorporating additional raters in the analytic process (see Northcutt 1999) would reduce this problem. Despite this limitation we consider that the data presented here provide a satisfactory account of the role of anxiety in foreign language learning for these students because they were strictly based on their own experiences and in their specific language learning context.

\section{REFERENCES}

Aida, Yukie. 1994. Examination of Horwitz, Horwitz, and Cope's construct of foreign language anxiety: The case of students of Japanese. The Modern Language Journal 78(2). 155168.

Arnaiz, Patricia \& Félix Guillén. 2012. Foreign language anxiety in a Spanish university setting: Interpersonal differences. Revista de Psicodidáctica 17(1). 5-26.

Arnaiz Castro, Patricia, Marcos Peñate Cabrera \& Plácido Bazo Martínez. 2010. El efecto de la planificación en la expresión oral de alumnos de primaria. Porta Linguarum 14. 181196.

Atkinson, Rita L., Richard C. Atkinson, Edward E. Smith, Daryl J. Bem \& Susan NolenHoeksema. 1994. Pszichológia. Budapest: Osiris-Századvég.

Brown, James D. 2001. Using surveys in language programs. Cambridge, UK: Cambridge University Press.

Burden, Peter. 2004. The teacher as facilitator: Reducing anxiety in the EFL university classroom. JALT Hokkaido Journal 8. 3-18.

Chastain, Kenneth. 1975. Affective and ability factors in second language acquisition. Language Learning 25(1). 153-161.

Cheng, Yuh-show. 2002. Factors associated with foreign language writing anxiety. Foreign Language Annals 35(5). 647-656.

Clément, Richard, Zoltán Dörnyei \& Kimberly A. Noels. 1994. Motivation, self-confidence, and group cohesion in the foreign language classroom. Language Learning 44(3). 417448.

Dayhoff, Signe. 2000. Diagonally-parked in a parallel universe. Working through social anxiety. Placitas, New Mexico: Effectiveness-Plus Publications.

De Bot, Kees. 1996. Review article: The psycholinguistics of the output hypothesis. Language Learning 46(3). 529-555.

Dewaele, Jean-Marc. 2007. Predicting language learners' grades in the L1, L2, L3 and L4: The effect of some psychological and sociocognitive variables. International Journal of Multilingualism 4. 169-197. 
English Proficiency Index. 2012. EF Education First Limited. http://www.ef.com/epi/.

Ewald, Jennifer D. 2007. Foreign language learning anxiety in upper-level classes: Involving students as researchers. Foreign Language Annals 40. 122-142.

Frantzen, Diana \& Sally S. Magnan. 2005. Anxiety and the true beginner dynamic in beginning French and Spanish classes. Foreign Language Annals 38(2). 171-186.

Fukai, Miyuki. 2000. Foreign language anxiety and perspectives of American college students of Japanese in the United States: An exploratory study. Japanese-Language Education around the Globe 10. 21-41.

Ganschow, Leonore, Richard Sparks, Reed Anderson, James Javorshy, Sue Skinner \& Jon Patton. 1994. Differences in language performance among high-, average-, and lowanxious college foreign language learners. The Modern Language Journal 78. 41-55.

Gardner, Robert C. \& Peter D. MacIntyre. 1993. A student's contributions to second language learning. Part II: Affective variables. Language Teaching 26(1). 1-11.

Gregersen, Tammy \& Elaine K. Horwitz. 2002. Language learning and perfectionism: Anxious and non-anxious language learners' reactions to their own oral performance. The Modern Language Journal 86. 562-570.

Hewitt, Elaine \& Jean Stephenson. 2012. Foreign language anxiety and oral performance: A replication of Phillips's MLJ study. The Modern Language Journal 96(2). 170-189.

Horwitz, Elaine K. 1990. Attending to the affective domain in the foreign language classroom, in: S. Magnan (ed.). Shifting the instructional focus to the learner, 15-33. Middlebury, VT: Northeast Conference on the Teaching of Foreign Languages,

Horwitz, Elaine K. 1995. Student affective reactions and the teaching and learning of foreign languages. International Journal of Educational Research 23(7). 573-579.

Horwitz, Elaine K., Michael B. Horwitz \& Joann Cope. 1986. Foreign language classroom anxiety. The Modern Language Journal 70(2). 125-132.

Horwitz, Elaine K., Michael B. Horwitz \& Joann Cope. 1991. Foreign language classroom anxiety. In: Elaine K. Horwitz \& Dolly J. Young (eds.), Language Anxiety from Theory and Research to classroom implications, 27-33. Englewood Cliffs, NJ: Prentice Hall.

Kitano, Kazu. 2001. Anxiety in the college Japanese language classroom. The Modern Language Journal 85(4). 549-566.

Kondo, David S. \& Ying-Ling Yang. 2003. The English language classroom anxiety scale: Test construction, reliability, and validity. JALT Journal 25(2). 593-598.

Krashen, Stephen D. 1981. Second language acquisition and second language learning. Oxford: Pergamon Press Inc.

Krashen, Stephen D. 1982. Principles and practice in second language acquisition. Oxford: Pergamon Press Inc.

Liu, Meihua. 2006. Anxiety in Chinese EFL at different proficiency levels. System 34. 301-316.

MacIntyre, Peter D. 1995. How does anxiety affect second language learning? A reply to Sparks and Ganschow. The Modern Language Journal 79(1). 90-99.

MacIntyre, Peter D. \& Robert C. Gardner. 1991. Investigating language class anxiety using the focused essay technique. The Modern Language Journal 75(3). 296-304.

MacIntyre, Peter D. \& Robert C. Gardner. 1994. The subtle effects of language anxiety on cognitive processing in the second language. Language Learning 44(2). 283-305.

MacIntyre, Peter D., Kimberly A. Noels \& Richard Clément. 1997. Biases in self-ratings of second language proficiency: The role of language anxiety. Language Learning 47(2). 265-287. 
Martínez Baztán, Alfonso. 2008. La evaluación oral: Una equivalencia entre las guidelines de ACTFL y algunas escalas del MCER. Granada. Universidad de Granada.

Matsumoto, David, Tsutomu Kudoh, Klaus Scherer \& Harald Wallbott. 1988. Antecedents of and reactions to emotions in the United States and Japan. Journal of Cross-Cultural Psychology 19(3). 267-286.

Northcutt, Norvell. 1999. Qualitative analysis [Unpublished course supplement materials]. University of Texas, Austin.

Norton, Bonny. 2000. Identity and language learning: Gender, ethnicity and educational change. Harlow: Longman/Pearson Education.

Onwuegbuzie, Anthony J., Philip Bailey \& Christine E. Daley. 1999. Factors associated with foreign language anxiety. Applied Psycholinguistics 20(2). 217-239.

Oxford, Rebecca. 1999. Anxiety and the language learner: New insights. In: Jane Arnold (ed.), Affect in language learning, 58-67. Cambridge, UK: Cambridge University Press.

Price, Mary Lou. 1991. The subjective experience of foreign language anxiety: Interviews with highly anxious students. In: Elaine K. Horwitz \& Dolly J. Young (eds.), Language anxiety: From theory and research to classroom implications, 101-108. Upper Saddle River, NJ: Prentice Hall.

Rifkin, Benjamin. 2000. Revising beliefs about foreign language learning. Foreign Language Annals 33(4). 394-420.

Saito, Yoshiko \& Keiko K. Samimy. 1996. Foreign language anxiety and language performance: A study of learner anxiety in beginning, intermediate, and advanced-level college students of Japanese. Foreign Language Annals 29(2). 239-249.

Samimy, Keiko K. 1994. Teaching Japanese: Consideration of learners' affective variables. Theory into Practice 33(1). 29-33.

Schlenker, Barry R. \& Mark R. Leary. 1985. Social anxiety and communication about the self. Journal of Language and Social Psychology 4(3-4). 171-192.

Scovel, Thomas. 1978. The effect of affect on foreign language learning: A review of the anxiety research. Language Learning 28(1). 129-142.

Spielmann, Guy \& Mary L. Radnofsky. 2001. Learning language under tension: New directions from a qualitative study. The Modern Language Journal 85(2). 259-278.

Spolsky, Bernard. 1989. Conditions for second language learning. Oxford: Oxford University Press.

Stroud, Cristopher \& Lionel Wee. 2006. Anxiety and identity in the language classroom. RELC Journal 37(3). 299-307.

Swain, Merryl. 1995. Three functions of output in second language learning. In: Guy Cook \& Barbara Seidlhofer (eds.), Principle and Practice in Applied Linguistics, 125-144. Oxford: Oxford University Press.

Suwantarathip, Ornprapat \& Saovapa Wichadee. 2010. The impacts of cooperative learning on anxiety and proficiency in an EFL class. The Journal of College Teaching and Learning 7(11). 51-57.

Tobias, Sheila. 1986. Anxiety and cognitive processing of instruction. In: R. Schwarzer (ed.), Self-related cognition in anxiety and motivation, 35-53. Hillsdale, NJ: Lawrence Erlbaum.

Tóth, Zsuzsa. 2007. Predictors of foreign-language anxiety: Examining the relationship between anxiety and other individual learner variables. In: József Horváth \& Marianne Nikolov (eds.), UPRT 2007: Empirical studies in English applied linguistics, 123148. Pécs: Lingua Franca Csoport. 
Wesely, Pamela M. 2012. Learner attitudes, perceptions, and beliefs in language learning. Foreign Language Annals 45(1). 98-117.

Williams, Kenneth E. \& Melvin R. Andrade. 2008. Foreign language learning anxiety in Japanese EFL university classes: Causes, coping, and locus of control. Electronic Journal of Foreign Language Teaching 5(2). 181-191.

Yan, Jackie X. \& Elaine K. Horwitz. 2008. How anxiety interacts with other learner factors to influence language achievement: A theoretical model. Language Learning 58(1). 151-183.

Young, Dolly J. 1990. An investigation of students' perspectives on anxiety and speaking. Foreign Language Annals 23(6). 539-553.

Young, Dolly J. 1991. Creating a low-anxiety classroom environment: What does language anxiety research suggest? The Modern Language Journal 75(4). 426-437.

Zhang, Lawrence J. 2001. Exploring variability in language anxiety: Two groups of pre students learning ESL in Singapore. RELC Journal 32. 73-91. 